\title{
Estimating the contribution of bromoform to stratospheric bromine and its relation to dehydration in the tropical tropopause layer
}

\author{
B.-M. Sinnhuber ${ }^{1}$ and I. Folkins ${ }^{2}$ \\ ${ }^{1}$ Institute of Environmental Physics, University of Bremen, Bremen, Germany \\ ${ }^{2}$ Department of Physics and Atmospheric Science, Dalhousie University, Halifax, Nova Scotia, Canada
}

Received: 14 October 2005 - Published in Atmos. Chem. Phys. Discuss.: 19 December 2005

Revised: 20 April 2006 - Accepted: 20 October 2006 - Published: 23 October 2006

\begin{abstract}
The contribution of bromoform to the stratospheric bromine loading is estimated using the onedimensional tropical mean model of Folkins and Martin (2005), which is constrained by observed mean profiles of temperature and humidity. In order to reach the stratosphere, bromoform needs to be lifted by deep convection into the tropical tropopause layer (TTL), above the level of zero radiative heating. The contribution of bromoform to stratospheric bromine then depends critically on the rate of removal of the degradation products of bromoform (collectively called $\mathrm{Br}_{\mathrm{y}}$ here) from the TTL, which is believed to be due to scavenging by falling ice. This relates the transport of short-lived bromine species into the stratosphere to processes of dehydration in the TTL. In the extreme case of dehydration occurring only through overshooting deep convection, the loss of $\mathrm{Br}_{\mathrm{y}}$ from the TTL may be negligible and consequently bromoform will fully contribute with its boundary layer mixing ratio to the stratospheric bromine loading, i.e. with $3 \mathrm{pptv}$ for an assumed 1 pptv of bromoform in the boundary layer. For the other extreme that $\mathrm{Br}_{\mathrm{y}}$ is removed from the TTL almost instantaneously, the model calculations predict a contribution of about $0.5 \mathrm{pptv}$ for the assumed 1 pptv of boundary layer bromoform. While this gives some constraints on the contribution of bromoform to stratospheric bromine, a key uncertainty in estimating the contribution of short-lived bromine source gases to the stratospheric bromine loading is the mechanism and rate of removal of $\mathrm{Br}_{\mathrm{y}}$ within the TTL.
\end{abstract}

\section{Introduction}

In recent years it has been realized that in addition to the long-lived ozone depleting substances such as the CFCs or halons, short-lived halogen compounds can also contribute

Correspondence to: B.-M. Sinnhuber

(bms@iup.physik.uni-bremen.de) significantly to the stratospheric halogen loading (Ko et al., 2003). In particular short-lived bromine compounds can have a relatively large impact, as already a few parts per trillion by volume (pptv) of extra bromine in the stratosphere from short-lived source gases can lead to significant increases in stratospheric ozone depletion (Salawitch et al., 2005).

Bromoform $\left(\mathrm{CHBr}_{3}\right)$ is probably the most abundant shortlived bromine species and may be an important source for stratospheric bromine (Sturges et al., 2000). Bromoform is mainly emitted from the oceans with large regional differences in the emission rates and near surface air concentrations (Quack and Wallace, 2003; Quack et al., 2004). Average bromoform mixing ratios in the marine boundary layer are probably in the range of about 1 to 2 pptv (Ko et al., 2003), i.e., carrying about 3 to 6 pptv of bromine, but locally much higher mixing ratios have been observed (Quack and Wallace, 2003).

Two previous model studies (Dvortsov et al., 1999; Nielsen and Douglass, 2001) have concluded that bromoform may contribute about 1 pptv to the stratospheric bromine loading. Both model results indicated that about half of the supply of bromine to the stratosphere comes from oxidation of bromoform in the troposphere which is then transported as inorganic bromine $\left(\mathrm{Br}_{\mathrm{y}}\right)$ to the stratosphere (so called product gas injection, Ko et al., 2003) while the other half enters the stratosphere directly as bromoform (so called source gas injection). In addition to uncertainties in the rate of convective transport of bromoform into the upper troposphere and lower stratosphere, the critical point in these studies is the lifetime of $\mathrm{Br}_{\mathrm{y}}$ in the troposphere.

The most important pathway of air entering the stratosphere is in the tropics through the tropical tropopause layer (TTL). In order to reach the stratosphere, air masses need to be lifted by deep convection above the level of zero radiative heating (Fig. 1). The level of zero radiative heating marks the transition from large-scale subsidence to large scale ascent, as diagnosed from diabatic heating rates $\left(\omega_{r}\right)$. The

Published by Copernicus GmbH on behalf of the European Geosciences Union. 


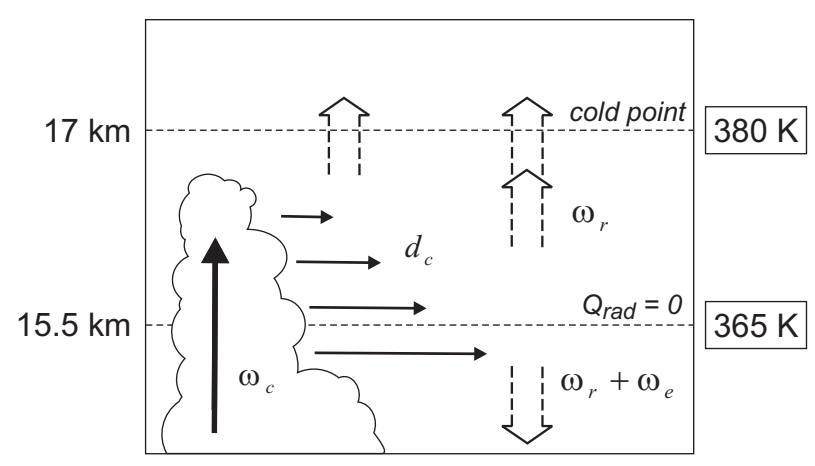

Fig. 1. Schematic overview of transport in the tropical tropopause region. The level of zero radiative heating at an altitude of about $15.5 \mathrm{~km}$ (about $365 \mathrm{~K}$ potential temperature) marks the transition from large scale subsidence to large scale ascent, as diagnosed from diabatic heating rates $\left(\omega_{r}\right)$. Any material transported into the stratosphere through the tropical tropopause thus has to be transported upward by deep convection $\left(\omega_{c}\right)$ and detrain above the level of zero radiative heating (with detrainment rate $d_{c}$, schematically indicated by horizontal arrows). The line at $17 \mathrm{~km}$ (about $380 \mathrm{~K}$ potential temperature) indicates the approximate position of the cold point tropopause. See also the text in Sect. 2.1 for further discussion.

divergence in the large-scale vertical velocities is balanced by detrainment from deep convection (with detrainment rate $d_{c}$ ). Note that only air masses detraining from deep convection above the level of zero radiative heating (at an altitude of about $15.5 \mathrm{~km}$, or about $365 \mathrm{~K}$ potential temperature) will reach the stratosphere. This makes the level of zero radiative heating a useful definition for the lower boundary of the TTL.

The other important level to be considered here is the cold point (at an altitude of about $17 \mathrm{~km}$ or about $380 \mathrm{~K}$ potential temperature): air masses reaching the stratosphere need to be dehydrated to mixing ratios corresponding roughly to the saturation mixing ratio at the cold point. The mechanism of dehydration in the TTL is not well understood and different hypotheses are currently being discussed. In one possible scenario, dehydration occurs gradually during large scale ascent. It has been realized (Holton and Gettelman, 2001) that during the relatively slow ascent through the TTL there is a high probability for airmasses being transported horizontally through the coldest regions of the tropical tropopause. In such a scenario, scavenging by falling ice could lead to some loss of $\mathrm{Br}_{\mathrm{y}}$ from the TTL. In a different scenario (Sherwood and Dessler, 2000), dehydration may occur completely in overshooting convection so that air detraining from deep convection is already dry. In such a scenario, the loss of $\mathrm{Br}_{\mathrm{y}}$ from the TTL may be negligible. In any case, the rate of removal of $\mathrm{Br}_{\mathrm{y}}$ from the TTL is highly uncertain, depending not only on the mechanism of dehydration, but also on the chemical partitioning of $\mathrm{Br}_{\mathrm{y}}$ in the TTL. Here in this paper, the contribution of bromoform to the stratospheric bromine loading is estimated using the one dimensional tropical mean model of Folkins and Martin (2005), which is constrained by observed mean profiles of temperature and humidity. This removes some of the uncertainty of previous studies that relied on convective mass fluxes from parameterized convection schemes (e.g., Nielsen and Douglass, 2001). Because the rate of removal of $\mathrm{Br}_{\mathrm{y}}$ from the TTL is highly uncertain, depending on the mechanism of dehydration in the TTL, we perform calculations over a range of $\mathrm{Br}_{\mathrm{y}}$ lifetimes.

\section{Model}

\subsection{One-dimensional model}

The model calculations in this work use tropical mean convective mass fluxes from the diagnostic one-dimensional model of Folkins and Martin (2005), which is constrained by observed profiles of temperature and humidity. Briefly, downward mass fluxes in the clear sky part of the tropical atmosphere are calculated from radiative and evaporative cooling rates:

$\omega_{r}=\frac{Q_{r}}{\sigma}$

$\omega_{e}=-\frac{L_{v} e}{c_{p} \sigma}$,

with $Q_{r}$ the radiative cooling rate, $e$ the evaporative moistioning rate, $L_{v}$ the heat of vaporization, $c_{p}$ the specific heat, and $\sigma$ the static stability:

$\sigma=-\frac{T}{\theta} \frac{\partial \theta}{\partial p}$.

It is then assumed that the clear sky downward mass flux is balanced by an upward convective mass flux $\left(\omega_{c}\right)$ so that

$\omega_{r}+\omega_{e}+\omega_{c}=0$.

The vertical divergence of the convective mass flux then gives the convective detrainment rate

$d_{c}=\frac{\partial\left(\omega_{r}+\omega_{e}\right)}{\partial p}$.

Profiles of $\omega=\omega_{r}+\omega_{e}$ and $d_{c}$ are shown in Fig. 2. Note that $d_{c}$ is zero at and above the cold point. This is of some importance for the interpretation of the results of the present study, as it is assumed here that $\mathrm{Br}_{\mathrm{y}}$ is removed from the atmosphere by falling rain or ice only below the cold point. The convective turnover time (inverse of detrainment rate) used in the present study agrees well with estimates from Dessler (2002) in the TTL, based on measurements of ozone and carbon monoxide. However, while the detrainment rate from Folkins and Martin (2005) is zero above $17 \mathrm{~km}$, Dessler (2002) estimates a convective turnover time of 50 to 90 days at $17 \mathrm{~km}$. 
Using the vertical mass fluxes $\omega_{r}+\omega_{e}$ and the detrainment rate $d_{c}$ from Folkins and Martin (2005), tropical mean trace gas profiles can be calculated according to the following equation:

$$
\frac{\partial[X]}{\partial t}+\left(\omega_{r}+\omega_{e}\right) \frac{\partial[X]}{\partial p}=P-L[X]+d_{c}\left([X]_{c}-[X]\right)
$$

Here $[X]$ is the trace gas mixing ratio, $P$ and $L$ are the chemical production and loss rates, respectively, and $[X]_{c}$ is the trace gas mixing ratio of air parcels detraining from convective clouds, which is essentially a free parameter of the model. Folkins and Martin (2005) show that ozone profiles calculated from Eq. (6) agree well with observed tropical mean ozone profiles. Although the underlying assumption of the model that there is little exchange with the extratropical atmosphere is less well justified in the tropopause region (Folkins and Martin, 2005), modelled profiles of ozone and $\mathrm{CO}$ agree well with observations, even in the TTL (Folkins et al., 2006).

Here we now use Eq. (6) to calculate tropical mean profiles of bromoform and $\mathrm{Br}_{\mathrm{y}}$ :

$$
\begin{aligned}
& \frac{\partial\left[\mathrm{CHBr}_{3}\right]}{\partial t}+\left(\omega_{r}+\omega_{e}\right) \frac{\partial\left[\mathrm{CHBr}_{3}\right]}{\partial p} \\
& =-\frac{\left[\mathrm{CHBr}_{3}\right]}{\tau_{\text {chem }}}+d_{c}\left(\left[\mathrm{CHBr}_{3}\right]_{c}-\left[\mathrm{CHBr}_{3}\right]\right),
\end{aligned}
$$

$$
\begin{aligned}
& \frac{\partial\left[\mathrm{Br}_{\mathrm{y}}\right]}{\partial t}+\left(\omega_{r}+\omega_{e}\right) \frac{\partial\left[\mathrm{Br}_{\mathrm{y}}\right]}{\partial p} \\
& =3 \frac{\left[\mathrm{CHBr}_{3}\right]}{\tau_{\text {chem }}}-\frac{\left[\mathrm{Br}_{\mathrm{y}}\right]}{\tau_{w}}+d_{c}\left(0-\left[\mathrm{Br}_{\mathrm{y}}\right]\right) .
\end{aligned}
$$

For the calculation of bromoform, the surface mixing ratio is kept fixed (at 1 pptv unless otherwise noted) and it is assumed that air detraining from deep convection also carries $1 \mathrm{pptv}$ of bromoform. There is no in situ production of bromoform and the loss rate is specified by the chemical lifetime $\tau_{\text {chem }}$ of $\mathrm{CHBr}_{3}$ due to photolysis and reaction with $\mathrm{OH}$, as discussed in the next section. It is then assumed that every molecule of bromoform lost produces 3 molecules of $\mathrm{Br}_{\mathrm{y}}$. The only loss process of $\mathrm{Br}_{\mathrm{y}}$ in the atmosphere away from the boundary layer is through washout by falling ice or rain. This is in the model described by a washout time $\tau_{w}$. This washout time is essentially a free parameter that in the model calculations presented here is assumed to be constant throughout the troposphere and TTL up to the cold point. Because the major $\mathrm{Br}_{\mathrm{y}}$ species and in particular $\mathrm{HBr}$ are highly soluble, it is assumed here that air detraining from convection has zero $\mathrm{Br}_{\mathrm{y}}$. Note that our assumption that air detraining from deep convection has zero $\mathrm{Br}_{\mathrm{y}}$ effectively increases the overall tropospheric washout rate for $\mathrm{Br}_{\mathrm{y}}$, see Eq. (8).

The set of Eqs. (7) and (8) is solved numerically on a vertical grid with $200 \mathrm{~m}$ resolution using an upwind advection scheme with leap-frog time stepping over 500 days with a timestep of 0.01 days. The relatively long integration time
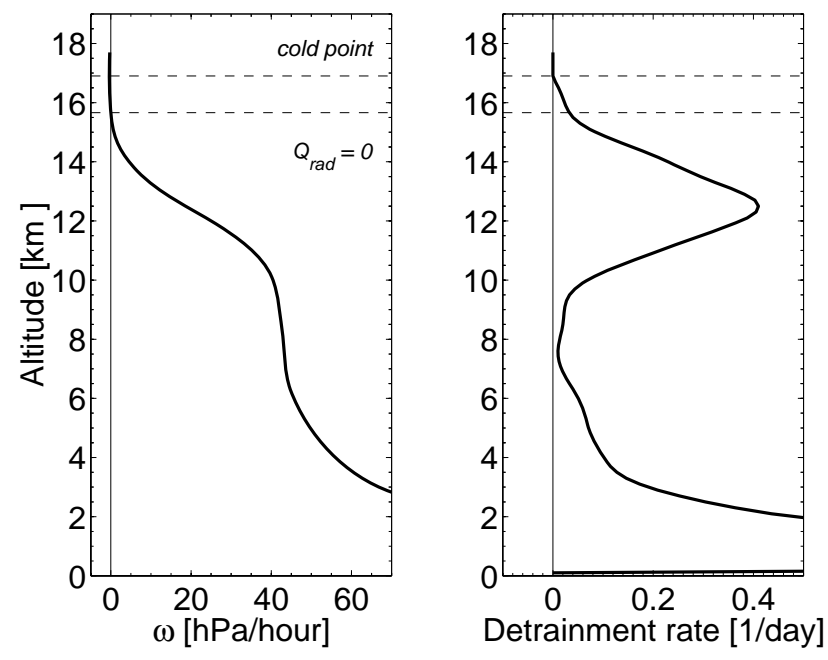

Fig. 2. Clear sky downward mass flux $\left(\omega=\omega_{r}+\omega_{e}\right.$, left panel) and detrainment rate $\left(d_{c}\right.$, right panel) from Folkins and Martin (2005). The dashed lines indicate the level of zero radiative heating (which marks the transition from large scale subsidence to large scale ascent) and the cold point.

is needed to reach a steady state solution in the lower stratosphere.

\subsection{Bromoform chemistry}

Loss of bromoform occurs mainly by photolysis and reaction with OH (Ko et al., 2003). Photolysis of bromoform is calculated here using the temperature dependent absorption cross sections from Sander et al. (2002) for a tropical atmosphere and averaged over the diurnal and annual cycles. Loss by reaction with $\mathrm{OH}$ is calculated using the temperature dependent reaction rate constant from Sander et al. (2002) and the idealized OH profile of Nielsen and Douglass (2001). The resulting loss rates and corresponding lifetime of bromoform are shown in Fig. 3. It is clear that uncertainties in the assumed $\mathrm{OH}$ profile will have only a minor impact on the calculated total bromoform loss rate because except for the lower troposphere the total loss is dominated by the photolysis rate.

Here we assume that the loss of $\mathrm{CHBr}_{3}$ either due to photolysis or reaction with $\mathrm{OH}$ immediately produces three $\mathrm{Br}_{\mathrm{y}}$ molecules. In reality $\mathrm{CHBr}_{3}+\mathrm{OH}$ probably leads to $\mathrm{Br}_{2} \mathrm{CO}+\mathrm{Br}$ and photolysis of $\mathrm{CHBr}_{3}$ leads to $\mathrm{HBrCO}+2 \mathrm{Br}$ or $\mathrm{Br}_{2} \mathrm{CO}+\mathrm{Br}$ as well (Weller et al., 1992). Little is known on the photochemical lifetimes of $\mathrm{Br}_{2} \mathrm{CO}$ or $\mathrm{HBrCO}$.

\section{Results and discussion}

The calculated tropical mean bromoform profile using the mass fluxes and chemical loss rates of Sect. 2 is shown in Fig. 4. The model calculations are compared with 

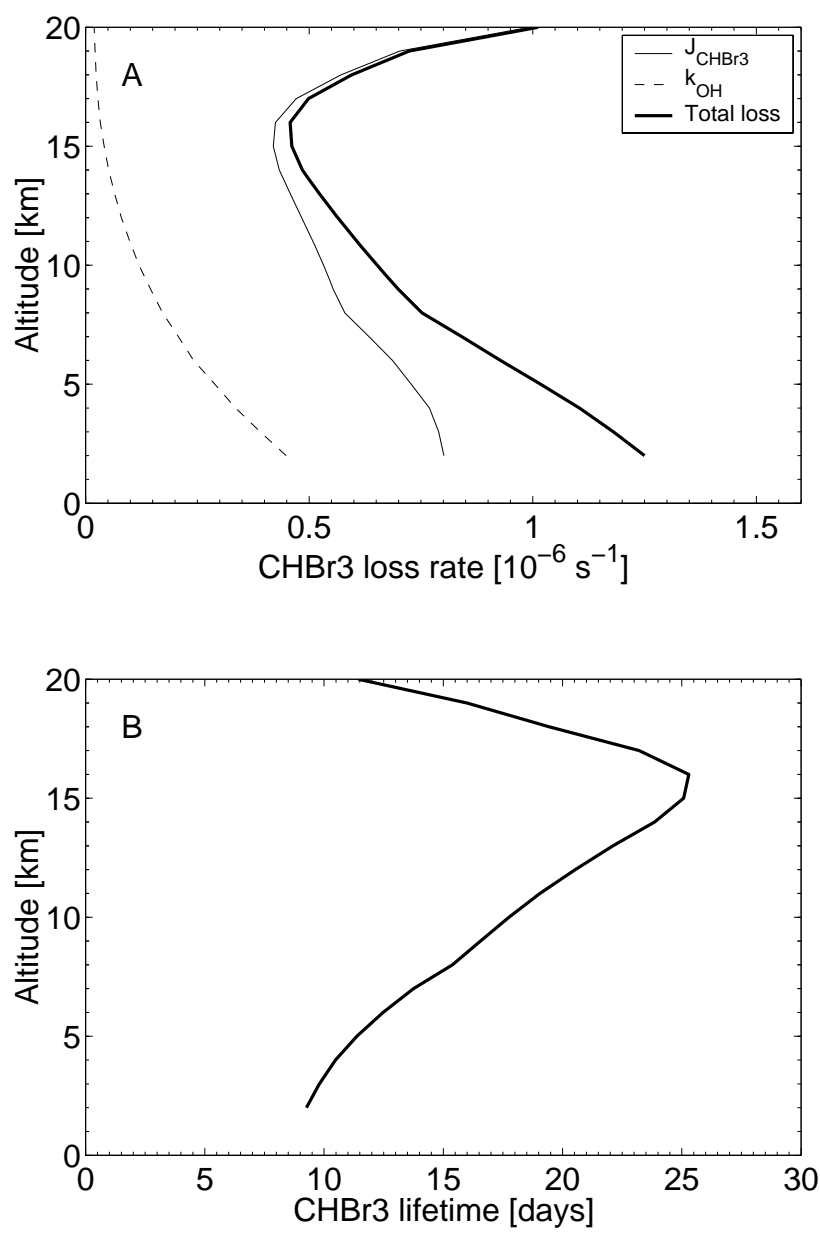

Fig. 3. (a) Calculated bromoform loss rates from photolysis (thin solid line) and reaction with $\mathrm{OH}$ (dashed line) for a tropical mean profile, together with the total loss rate (thick solid line). (b) Bromoform lifetime $\tau_{\text {chem }}$ in days (inverse of total loss rate).

bromoform observations from the NASA DC-8 aircraft during the PEM Tropics-A campaign and from the NASA WB57 high-altitude aircraft during the ACCENT and Pre Aura Validation Experiment (Pre-AVE) campaigns. The observations during PEM Tropics-A were performed in the Central and Eastern Pacific during August to October 1996. The PEMTropics data shown here were taken from the compilation of aircraft measurements by Emmons et al. (2000). Observations during ACCENT were performed during April and September 1999 between $5^{\circ} \mathrm{N}$ and $40^{\circ} \mathrm{N}$ at around $90^{\circ} \mathrm{W}$ (e.g., Tuck et al., 2004). The Pre-AVE observations considered here were taken in January and February 2004 between $20^{\circ} \mathrm{N}$ and $3^{\circ} \mathrm{S}$ at around $90^{\circ} \mathrm{W}$. Indicated in Fig. 4 are the mean values and the range between minimum and maximum values over all measurements between $3^{\circ} \mathrm{S}$ and $20^{\circ} \mathrm{N}$. The model calculations of bromoform agree reasonably well with the mean bromoform profile from the three campaigns, in particular if a mean boundary layer and detrainment mix-

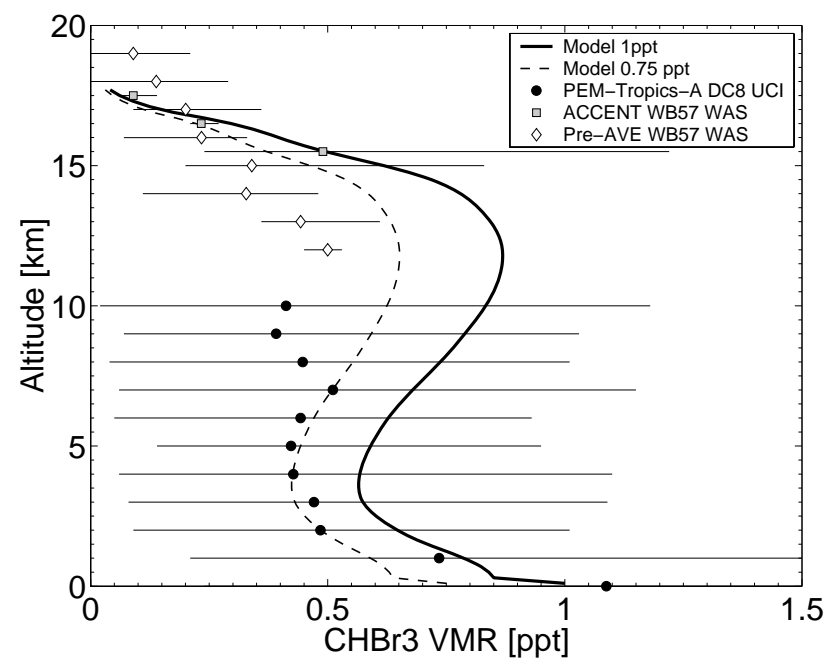

Fig. 4. Modeled profile of bromoform assuming $1 \mathrm{pptv}$ (solid line) and $0.75 \mathrm{pptv}$ (dashed line) in the boundary layer, together with observations of bromoform from the PEM Tropics-A (August to October 1996, dots), ACCENT (April and September 1999, squares) and Pre-AVE (January and February 2004, diamonds) campaigns. For the campaign data mean values and the range between minimum and maximum values of the individual observations between $3^{\circ} \mathrm{S}$ and $20^{\circ} \mathrm{N}$ are shown.

ing ratio of $0.75 \mathrm{pptv}$ is assumed in the model calculations (dashed line). (Note that the model results are linear in the assumed detrainment mixing ratios.) However, one has to be careful not to overinterpret the comparison between model and observations. It is not clear how representative the bromoform observations during the PEM Tropics-A, ACCENT and Pre-AVE campaigns are for the tropics in general, given the relatively large variability of bromoform. Observations during the STRAT campaign in 1996 showed much smaller bromoform values in the upper troposphere and lower stratosphere (Nielsen and Douglass, 2001) with most bromoform measurements below detection limit, resulting in a mean bromoform profile close to zero. The differences in the bromoform profiles between STRAT on the one hand side and ACCENT and Pre-AVE on the other hand probably reflect differences in the activity of deep convection between the campaigns.

The flux of bromoform into the model atmosphere in order to maintain the modelled steady state bromoform profile for a boundary layer values of $1 \mathrm{pptv}$ equals $1.1 \times 10^{12} \mathrm{molec} / \mathrm{cm}^{2} /$ day. If one assumes a uniform oceanic source this corresponds to a global flux of $0.6 \mathrm{Tg} \mathrm{CHBr} 3 /$ year (taking the area of Earth' oceans as $3.61 \times 10^{14} \mathrm{~m}^{2}$ ). This value is higher than the one given in the previous WMO/UNEP assessment $(0.2 \mathrm{Tg}$ /year, Ko et al., 2003) but agrees (in particular when scaled to a boundary layer value of 0.75 pptv) with the modelling studies of Nielsen and Douglass (2001, 0.5 Tg/year) and Yang et al. (2005, 0.4 Tg/year). 
The model calculations of total bromine emitted from bromoform (defined as $\mathrm{Br}_{\mathrm{y}}+3 \times \mathrm{CHBr}_{3}$ ) are shown in Fig. 5 . The results shown here assume a mean boundary layer and detrainment mixing ratio of $1 \mathrm{pptv}$. As the model results are linear in the bromoform detrainment mixing ratios they can be directly scaled to give results for different boundary layer bromoform mixing ratios. The calculations here are performed for a range of $\mathrm{Br}_{\mathrm{y}}$ lifetimes between 0 days (i.e. instantaneous removal of $\mathrm{Br}_{\mathrm{y}}$ ) and infinity (i.e. no loss of $\mathrm{Br}_{\mathrm{y}}$ from the TTL). Most model calculations assume or compute a mean tropospheric washout lifetime of $\mathrm{Br}_{\mathrm{y}}$ of about 10 to 30 days (Dvortsov et al., 1999; Nielsen and Douglass, 2001; von Glasow et al., 2004), although these studies do not specifically report the washout time in the TTL. In our model a washout time of 10 to 30 days in the TTL results in about 1 pptv of total bromine in the stratosphere due to bromoform (assuming a mean boundary layer mixing ratio of $1 \mathrm{pptv}$ ), confirming the results of the previous studies by Dvortsov et al. (1999) and Nielsen and Douglass (2001).

For a $\mathrm{Br}_{\mathrm{y}}$ lifetime of 0 days the contribution of bromoform to stratospheric bromine is about 0.5 pptv. This situation constitutes a lower limit for the bromine contribution due to bromoform (i.e., source gas injection only) and could - at least in principle - be derived from bromoform measurements in the TTL.

At the opposite extreme is the situation, where the loss of $\mathrm{Br}_{\mathrm{y}}$ from the TTL is negligible (inifite $\mathrm{Br}_{\mathrm{y}}$ lifetime). For this case we expect that the mixing ratio of bromoform detraining from deep convection in the TTL will fully contribute to the stratospheric bromine loading, i.e., the assumed $1 \mathrm{pptv}$ of bromoform in the boundary layer will add 3 pptv to the stratospheric bromine loading. However, this situation constitutes only an upper boundary for the contribution of bromoform to the stratospheric bromine loading if it is assumed that air detraining from deep convection does not contain any $\mathrm{Br}_{\mathrm{y}}$. In reality a certain fraction of the inorganic bromine $\left(\mathrm{Br}_{\mathrm{y}}\right)$ in the troposphere will consist of species with low solubility (most importantly bromine monoxide, $\mathrm{BrO}$ ) so that $\mathrm{Br}_{\mathrm{y}}$ could be transported into the TTL by deep convection.

Unfortunately the tropospheric bromine chemistry is not well understood at present: Indications for a global mean background of about $1 \mathrm{pptv}$ of $\mathrm{BrO}$ in the troposphere (e.g., Sinnhuber et al., 2005) would require - according to our present understanding of the tropospheric bromine chemistry - an additional unknown source of bromine (von Glasow et al., 2004). Current models predict a large $\mathrm{HBr} / \mathrm{BrO}-$ ratio in the free troposphere, so that most of the tropospheric inorganic bromine resides in the form of $\mathrm{HBr}$ which is highly soluble. However, heterogeneous recycling of $\mathrm{Br}_{\mathrm{y}}$ as discussed in general terms by Platt and Hönninger (2003) and more specifically by the recent laboratory study of Iraci et al. (2005) could lead to a higher $\mathrm{BrO} / \mathrm{Br}_{\mathrm{y}}$-ratio in the troposphere. This would then effectively increase the washout lifetime $\tau_{w}$ and could thus increase the product gas injection pathway for bromoform.

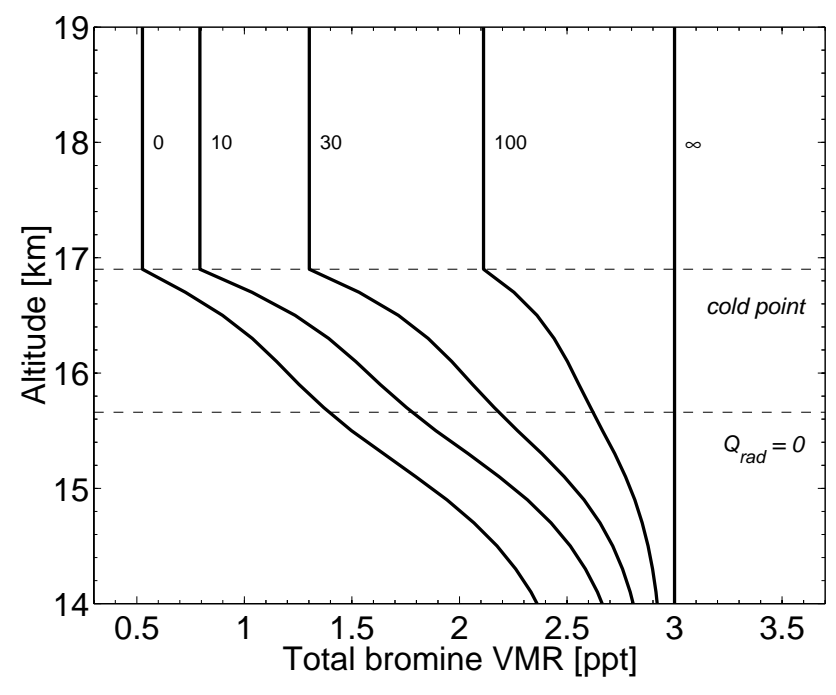

Fig. 5. Calculated total bromine released from bromoform (defined as $\mathrm{Br}_{\mathrm{y}}+3 \times \mathrm{CHBr}_{3}$ ) for different washout rates of $\mathrm{Br}_{\mathrm{y}}$ (numbers in the figure give $\tau_{w}$ in days, the lifetime of $\mathrm{Br}_{\mathrm{y}}$ due to washout). The calculations assume 1 pptv of bromoform in the boundary layer and no detrainment of $\mathrm{Br}_{\mathrm{y}}$ from convection (see text for discussion).

Without a better understanding of the $\mathrm{Br}_{\mathrm{y}}$ lifetime in the TTL - and thus a better understanding of the mechanisms of dehydration in the TTL - it will probably not be possible to get a precise estimate for the contribution of bromoform to stratospheric bromine. From the present study our best estimate is somewhere between 1 and 3 pptv. This number is basically consistent with estimates of the contribution from short-lived bromine compounds based on measurements of $\mathrm{BrO}$ in the stratosphere (Pfeilsticker et al., 2000; Sinnhuber et al., 2002, 2005; Salawitch et al., 2005).

The results presented here for bromoform could in principle also being applied to other short-lived bromine gases such as $\mathrm{CH}_{2} \mathrm{BrCl}, \mathrm{CH}_{2} \mathrm{Br}_{2}, \mathrm{CHBrCl}_{2}$ and $\mathrm{CHBr}_{2} \mathrm{Cl}$. However, these substances have lifetimes of 70 to 150 days (Ko et al., 2003) as compared to about 25 days for $\mathrm{CHBr}_{3}$. Moreover, they contain only one or two bromine atoms, as compared to three for $\mathrm{CHBr}_{3}$. Consequently, for these substances the transport of degradation products $\left(\mathrm{Br}_{\mathrm{y}}\right)$ into the stratosphere (more specifically the ratio of product gas injection to source gas injection) will be less important than it is for bromoform (Ko et al., 1997). Thus alternatively their contribution to the stratospheric bromine loading may be estimated similar to that of long-lived species, e.g. through observed correlations with CFC-11 (Wamsley et al., 1998).

\section{Conclusions}

We have presented an estimate for the contribution of bromoform to the stratospheric bromine loading, based on the one-dimensional model of Folkins and Martin (2005). Our 
model calculates profiles of bromoform and its degradation products (called $\mathrm{Br}_{\mathrm{y}}$ here) for a tropical mean atmosphere, ignoring any exchange with the extratropics. In particular, we have studied how the calculated contribution of bromoform to the stratospheric bromine loading depends on the rate of removal of $\mathrm{Br}_{\mathrm{y}}$ within the TTL. With reasonable assumptions for the mean bromoform mixing ratio in the tropical boundary layer of about $1 \mathrm{pptv}$ and for the lifetime of $\mathrm{Br}_{\mathrm{y}}$ due to washout of 10 to 30 days in the TTL the calculations show that bromoform contributes about 1 pptv to the stratospheric bromine loading. This confirms earlier results that used similar assumptions (Dvortsov et al., 1999; Nielsen and Douglass, 2001). One improvement compared to these earlier studies is that here we use tropical mean convective mass fluxes that are diagnosed from observations. This removes part of the uncertainty of previous studies that rely on convective mass fluxes from parameterized convection schemes. The fact that the calculated tropical mean bromoform profile agrees reasonably well with available observations gives some confidence. However, given the relatively large variability of bromoform in the atmosphere and the sparseness of available observations in the deep tropics it is not clear how representative the available observations are.

One important result of our study is that the contribution of bromoform to the stratospheric bromine loading depends critically on the loss of $\mathrm{Br}_{\mathrm{y}}$ due to falling rain or ice. In fact, what is of importance here is the lifetime of $\mathrm{Br}_{\mathrm{y}}$ in the TTL between the level of zero radiative heating and the cold point (Fig. 5). Knowledge of the mechanisms and rates of dehydration in the TTL are very limited at present, which limits our ability to estimate the contribution of bromoform to stratospheric bromine.

In the extreme case that all dehydration in the TTL occurs already in overshooting deep convection (Sherwood and Dessler, 2000) the loss of $\mathrm{Br}_{\mathrm{y}}$ from the TTL may be negligible. In this case bromoform will contribute fully with its boundary layer mixing ratio to the stratospheric bromine loading, i.e., with 3 pptv for an assumed mean boundary layer mixing ratio of 1 pptv. In principle this value could be even higher if also degradation products of bromoform are transported into the TTL by deep convection. (Our calculations here assumed that the degradation products - collectively called $\mathrm{Br}_{\mathrm{y}}$ here - are soluble and will be removed in deep convecting clouds.)

Our ability to quantify the contribution of bromoform to stratospheric bromine is thus not only limited by uncertainties in the strength and distribution of bromoform sources and the transport of bromoform into the tropopause region, but also by the loss rate of $\mathrm{Br}_{\mathrm{y}}$ in the TTL, which depends on the mechanism of dehydration in the TTL.
Acknowledgements. Parts of this work were supported by the EU project SCOUT-O3 and by the Helmholtz Virtual Institute Pole-Equator-Pole. We thank E. Atlas for making the bromoform measurements during ACCENT and Pre-AVE available to us and for helpful discussions regarding the data. Comments from M. Ko, R. Salawitch and an anonymous reviewer are gratefully acknowledged.

Edited by: P. Haynes

\section{References}

Dessler, A. E.: The effect of deep, tropical convection on the tropical tropopause layer, J. Geophys. Res., 107, 4033, doi:10.1029/2001JD000511, 2002.

Dvortsov, V. L., Geller, M. A., Solomon, S., Schauffler, S. M., Atlas, E. L., and Blake, D. R.: Rethinking reactive halogen budgets in the mid-latitude lower stratosphere, Geophys. Res. Lett., 26, 1699-1702, 1999.

Emmons, L. K., Hauglustaine, D. A., Müller, J.-F., Carroll, M. A., Brasseur, G. P., Brunner, D., Staehlin, J., Thouret, V., and Marenco, A.: Data composites of airborne observations of tropospheric ozone and its precursors, J. Geophys. Res., 105, $20497-$ 20 536, 2000.

Folkins, I. and Martin, R. V.: The vertical structure of tropical convection and its impact on the budgets of water vapor and ozone, J. Atmos. Sci., 62, 1560-1573, 2005.

Folkins, I., Bernath, P., Boones, C., et al.: Testing convective parameterizations with tropical measurements of $\mathrm{HNO}_{3}, \mathrm{CO}, \mathrm{H}_{2} \mathrm{O}$, and $\mathrm{O}_{3}$ : implications for the water vapor budget, J. Geophys. Res., in press, 2006.

Holton, J. R. and Gettelman, A.: Horizontal transport and the dehydration of the stratosphere, Geophys. Res. Lett., 28, 2799-2802, 2001.

Iraci, L. T., Michelsen, R. R., Ashbourn, S. F. M., Rammer, T. A., and Golden, D. M.: Uptake of hypobromous acid (HOBr) by aqueous sulfuric acid solutions: low-temperature solubility and reaction, Atmos. Chem. Phys., 5, 1577-1587, 2005, http://www.atmos-chem-phys.net/5/1577/2005/.

Ko, M. K. W., Sze, N.-D., Scott, C. J., and Weisenstein, D. K.: On the relation between stratospheric chlorine/bromine loading and short-lived tropospheric source gases, J. Geophys. Res., 102, 25 507-25 517, 1997.

Ko, M. K. W., Poulet, G., Blake, D. R., et al.: Very short-lived halogen and sulfur substances, Chapter 2, in: Scientific Assessment of Ozone Depletion: 2002, Global Ozone Research and Monitoring Project - Report No. 47, World Meteorological Organization, Geneva, 2003.

Nielsen, J. E. and Douglass, A. R.: A simulation of bromoform's contribution to stratospheric bromine, J. Geophys. Res., 106, 8089-8100, 2001.

Platt, U. and Hönninger, G., The role of halogen species in the troposphere, Chemosphere, 52, 325-338, 2003.

Pfeilsticker, K., Sturges, W. T., Bösch, H., Camy-Peyret, C., Chipperfield, M. P., Engel, A., Fitzenberger, R., Müller, M., Payan, S., and Sinnhuber, B.-M.: Lower stratospheric organic and inorganic bromine budget for the arctic winter 1998/99, Geophys. Res. Lett., 27, 3305-3308, 2000. 
Quack, B. and Wallace, D. W. R.: Air-sea flux of bromoform: Controls, rates, and implications, Global Biogeochem. Cycles, 17, 1023, doi:10.1029/2002GB001890, 2003.

Quack, B., Atlas, E., Petrick, G., Stroud, V., Schauffler, S., and Wallace, D. W. R.: Oceanic bromoform sources for the tropical atmosphere, Geophys. Res. Lett., 31, L23S05, doi:10.1029/2004GL020597, 2004.

Salawitch, R. J., Weisenstein, D. K., Kovalenko, L. J., Sioris, C. E., Wennberg, P. O., Chance, K., Ko, M. K. W., and McLinden, C. A.: Sensitivity of ozone to bromine in the lower stratosphere, Geophys. Res. Lett., 32, L05811, doi:10.1029/2004GL021504, 2005.

Sander, S. P., Finlayson-Pitts, B. J., Friedl, R. R., et al.: Chemical Kinetics and Photochemical Data for Use in Stratospheric Modeling, Evaluation No. 14, NASA JPL Publication 02-25, 2002.

Schauffler, S. M., Atlas, E. L., Blake, D. R., Flocke, F., Lueb, R. A., Lee-Taylor, J. M., Stroud, V., and Travnicek, W.: Distributions of brominated organic compounds in the troposphere and lower stratosphere, J. Geophys. Res., 104, 21 513-21 535, 1999.

Sherwood, S. C. and Dessler, A. E.: On the control of stratospheric humidity, Geophys. Res. Lett., 27, 2513-2516, 2000.

Sinnhuber, B.-M., Arlander, D. W., Bovensmann, H., et al.: Comparison of measurements and model calculations of stratospheric bromine monoxide, J. Geophys. Res., 107, 4398, doi:10.1029/2001JD000940, 2002.
Sinnhuber, B.-M., Rozanov, A., Sheode, N., et al.: Global observations of stratospheric bromine monoxide from SCIAMACHY, Geophys. Res. Lett., 32, L20810, doi:10.1029/2005GL023839, 2005.

Sturges, W. T., Oram, D. E., Carpenter, L. J., Penkett, S. A., and Engel, A.: Bromoform as a source of stratospheric bromine, Geophys. Res. Lett., 27, 2081-2084, 2000.

Tuck, A. F., Hovde, S. J., Kelly, K. K., et al.: Horizontal variability $1-2 \mathrm{~km}$ below the tropical tropopause, J. Geophys. Res., 109, D05310, doi:10.1029/2003JD003942, 2004.

von Glasow, R., von Kuhlmann, R., Lawrence, M. G., Platt, U., and Crutzen, P. J.: Impact of reactive bromine chemistry in the troposphere, Atmos. Chem. Phys., 4, 2481-2497, 2004, http://www.atmos-chem-phys.net/4/2481/2004/.

Wamsley, P. R., Elkins, J. W., Fahey, D. W., et al.: Distribution of halon-1211 in the upper troposphere and lower stratosphere and the 1994 total bromine budget, J. Geophys. Res., 103, 15131526, 1998.

Weller, R., Lorenzen-Schmidt, H., and Schrems, O.: FTIR studies on the photooxidation mechanisms of $\mathrm{CH}_{3} \mathrm{Cl}, \mathrm{CH}_{3} \mathrm{Br}, \mathrm{CHBr}_{3}$, and $\mathrm{CF}_{3} \mathrm{Br}$, Ber. Bunsenges. Phys. Chem., 96, 409-413, 1992.

Yang, X., Cox, R. A., Warwick, N. J., Pyle, J. A., Carver, G. D., O'Connor, F. M., and Savage, N. H.: Tropospheric bromine chemistry and its impacts on ozone: A model study, J. Geophys. Res., 110, D23311, doi:10.1029/2005JD006244, 2005. 